\title{
Philosophical, anthropological and axiological aspects of Constantine's definition of philosophy
}

\begin{abstract}
Ján Zozul'ak ${ }^{1}$
Abstract

This paper focuses on the philosophical-ethical foundations of Constantine's definition of philosophy, as well as its anthropological and axiological aspects. The focus is placed on the relationship between definitions of philosophy postulated by Constantine the Philosopher and John of Damascus, the latter of which traces the six classical definitions systematized by Platonic commentators. Byzantine thinkers proposed a method of unifying both the theoretical and practical aspects of ancient philosophy with a Christian way of life by interpreting the classical definitions of philosophy and dividing it into theoretical and practical parts, the latter including ethics. Constantine understood philosophy in the sense of the second (knowledge of things Divine and human) and the fourth (becoming like God) meanings of earlier definitions, with the addition of the Christian sense of acting in accordance with the image of God. In addition to these gnosiological and anthropological aspects, the paper also observes the axiological aspect of Constantine's definition of philosophy, which appears to be a foundation for exploring human behaviour as in compliance with Christian laws encouraging changes in ethical principles so as to follow a new code of ethics, through which new values were presented to the Slavs.
\end{abstract}

Keywords: Constantine (Cyril), definition of philosophy, image, likeness, Byzantine anthropology

\section{Introduction}

This paper analyses the philosophical, anthropological and axiological aspects of Constantine's definition of philosophy and focuses on the selected ethical cornerstones of the CyrilloMethodian mission to the Slavic cultural space, to which Byzantine values cultivating human personality were being transferred through the works of the eponymous Constantine the Philosopher (Cyril) and Methodius. Brothers Constantine and Methodius became the link between Byzantine and Slavic cultures; a part of the immensely rich Byzantine culture, education, and thinking was brought to Great Moravia through their work, contributing to the intellectual elevation of the Slavs.

Through Christianity, the Cyrillo-Methodian mission (Ivanič, 2020, pp. 655-667) promoted, among the Slavs, new values and a new code of ethics, which was closely related to the new understanding of the world and of the position of man in it. The Byzantine Emperor Michael III encouraged Prince Rastislav to promote these new - Christian - values, which were to become the pillars of all the Slavic nations. He encouraged Rastislav to "search for God with all his heart” (Život Konštantína-Cyrila, 2013, p. 33). He continues:

Nor spurn the salvation of people, but foster all, so that they set off on a path of truth without hesitation; so that you, too, would be repaid today and in future for your effort, for showing them the knowledge of God, for all those souls who will turn to Christ our Lord, from now on and forever, leaving your legacy to later generations like the great emperor Constantine! (Život Konštantína-Cyrila, 2013, p. 33).

The import of the Byzantine mission lies especially in the fact that it elevated Great Moravian Slavs and significantly contributed to the cultural upswing of other Slavic nations of Eastern Europe and the Balkans, which developed their cultures on a basis of common mentality and values for many centuries. Simultaneously, the mission of St. Constantine-Cyril and Methodius to Great Moravia in 863 casts light on the methods of contemporary Byzantine

\footnotetext{
${ }^{1}$ Constantine the Philosopher University in Nitra (Slovakia); email: jzozulak@ukf.sk, ORCID ID: 0000-0001$5263-1224$
} 
diplomacy, as pointed out by Nikos Matsoukas: "The respect for the languages and cultures of other nations corresponds with Byzantine philosophy, which [...] contributed to the flourishing of culture without racial, ethnic and language prejudice" (Matsoukas, 2010, p. 432). This innovative policy is an example of the sophistication of Byzantine culture, which - by virtue of the Cyrillo-Methodian mission - allowed Slavs to become a developed nation and further advance their own culture, language and thought.

\section{Philosophical aspect of Constantine's definition of philosophy}

Let us first briefly explain the background information on Constantine's philosophical education, starting with his mentor, Photios the Great - an exquisite philosopher, theologian and historian, who contributed to the flourishing of Greek writing and became a leading representative of Byzantine humanism. In this period, ${ }^{2}$ Byzantine humanists laid the foundations for the revival of the study of ancient philosophical texts and art (Stavrianos, 2014, pp. 33-34). An increase in attention paid to classical studies also took the form of transcribing and circulating selected texts. In this regard, Photios the Great issued and commented on works by ancient philosophers with the help of his colleagues, among them Constantine the Philosopher, who acquired a remarkable education before coming to Great Moravia, "[he] studied Homer and geometry, was lectured in dialectics and all philosophy by Leo and Photios, and studied rhetoric and arithmetic, astronomy and music and all other Greek arts" (Život Konštantína-Cyrila, 2013, p. 15)

The Moravian-Pannonian text Život Konštantína-Cyrila [The Life of Constantine-Cyril] states that Constantine answered the question of what philosophy is as follows: "The knowledge of matters Divine and human, to what extent man can approach God. It teaches man to be in the image and likeness of the One who created him" (Život Konštantína-Cyrila 2013, p. 16).

If we accept the premise that the first contact of the Slavic cultural space within the area of Great Moravia with Byzantine philosophy took place via this text, it is evident that this "definition" of philosophy, likely the first to be presented in a Slavic language (Dupkala, 2006, pp. 95-102), hides not only the direct impact of ancient thought, but - most importantly - the key to understanding basic values, then being transferred to Slavic countries from the Byzantine cultural space, which was, on the one hand, a continuation of ancient Greek culture and on the other enriched with a Christian dimension (Tatakis, 1967, p. 174).

According to František Dvorník, Constantine bases his definition of philosophy "on Stoic teaching that wisdom lies in the knowledge of matters Divine and human. The second part of Constantine's definition reminds [sic] of Plato's conclusion that man should, according to his capacity, grow to be in the image and likeness of God" (Dvorník, 1970, p. 78). Alexander Avenarius points out that recognition of the Stoic dimension (knowledge of things Divine and human) of this definition, present in its first part, and of the Platonic dimension (man becoming like God) in its second part carries with itself certain issues. He therefore explains:

It seems that [an] analytical approach and division of the definition into two parts has caused a marked overestimation of [the] ancient influences in the work of Constantine. This approach makes us lose sight of the total structure of the definition and of its fundamental meaning. It is undeniable that the definition, as such, respects in full extent the medieval opinion: the ancient influences which it is made up of provide a certain formal frame and they are subordinate to the idea that cognition is justified when it works towards knowledge of matters Divine. Cognition of matters human is tolerated here, or, its task is given by its function in the process of knowing of matters Divine, i.e. what is said here is a certain variation on a frequent topos of other contemporary

\footnotetext{
${ }^{2}$ This period is often called the Macedonian Renaissance, but this label has caused a heated discussion, as there is a considerable difference between the Renaissance in the East in the ninth century and the Renaissance in the West in the fifteenth century.
} 
Byzantine hagiographic works and on what proceeds also from the understanding of patristic literature. In Constantine's definitions nothing suggests that there would appear a truly humanist idea that would attribute autonomy to observing of the world and man, much less an equal gnosiological value (Avenarius, 1992, p. 71).

Definitions of philosophy similar to the one construed by Constantine can be found in many handbooks used at the University of Constantinople at the time (Ševčenko, 1956, p. 449). It needs to be mentioned, at least in passing that, in this era, a higher educational institute existed in Constantinople, which many scholars consider a university by contemporary standards. In

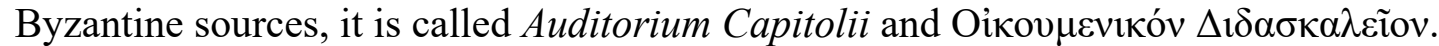

In an objective evaluation of Constantine's definition of philosophy, however, one cannot advance without a more complex knowledge of contemporary theology (Zozul'aková, 2016, p. 151), as, in addition to handbooks of this kind, Byzantine philosophical thought was significantly influenced by Greek scholasticism in the sixth century, and in the eighth century by the Dialectic of John of Damascus (c. 650-749), who collected Greek philosophical thought of the four pre-Christian centuries and Christian thought of the first eight centuries in the three volumes of The Fount of Knowledge, providing an answer to what philosophy is (John of Damascus, 1860a, p. 533).

John of Damascus uses six definitions of philosophy:

1) the knowledge of things which are insofar as they are $(\gamma v \tilde{\omega} \sigma \iota \varsigma \tau \tilde{\omega} v o ̋ \tau \tau \omega v, \tilde{\eta} \partial v \tau \alpha)$;

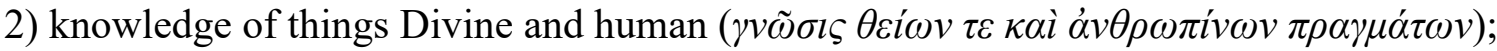

3) contemplation of death ( $\mu \varepsilon \lambda \dot{\varepsilon} \tau \eta \theta \alpha v \alpha \dot{\tau} \tau o v)$;

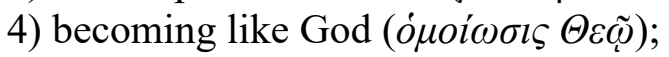

5) art of arts and science of sciences ( $\tau \dot{\varepsilon} \chi v \eta \tau \varepsilon \chi v \tilde{\omega} v \kappa \alpha i ̀ ~ \varepsilon \dot{\pi} \iota \sigma \tau \eta \dot{\mu} \mu \dot{\varepsilon} \pi \imath \sigma \tau \eta \mu \tilde{\omega} v)$;

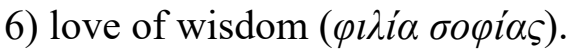

A later commentator, Nikephoros Blemmydes (1197-1272), writes that the first, second and sixth definitions of John of Damascus were originally postulated by Pythagoras, the third and fourth by Plato and the fifth by Aristotle (Nikephoros Blemmydes, 1865, p. 724). Various definitions of philosophy resonate in Byzantine works throughout the era, reiterating - with certain variations - these six classical definitions, systematized by Platonic commentators: Ammonius, David and Elias, among others (Ierodiakonou, 2010, p. 846; Milko, 2016, p. 122).

These definitions were typically coupled with a division of philosophy into theoretical and practical parts. Theoretical philosophy concerns itself with knowledge and comprises physics (dealing with material things), mathematics (geometry, arithmetic, astronomy, and harmonics), and theology (immaterial beings: God, angels, souls). Practical philosophy concerns itself with virtues and comprises ethics, economics and politics. In interpreting these definitions, Byzantine thinkers proposed a method of incorporating both theoretical and practical aspects of ancient philosophy into the Christian way of life. From the fourth century onwards, the term

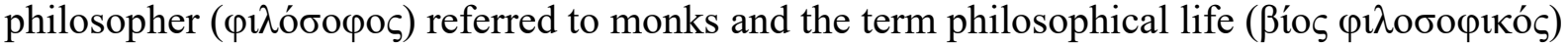
referred to monastic life. It is therefore understandable that, afterwards, for Byzantine thinkers, true philosophy is inseparably connected with asceticism and monasticism. "This may seem rather extreme and provocative, given the hostility of illiterate ascetics towards ancient Greek philosophy, but it should not escape us that in late antiquity one could be called a philosopher just by virtue of his way of everyday life, without necessarily adhering to, or for that matter introducing, a certain philosophical system" (Ierodiakonou, 2010, p. 847). Eunapius expressed the tenets of this understanding in his Lives of the Sophists; turning to Porphyry as an example, he stressed the equality of words and deeds, but also the necessity to apply philosophical knowledge in practical life, together with asceticism in a life devoted to philosophy (Dostálová, 2004, p. 11).

Among the most noteworthy sources form this era is the work of Athanasius the Great, Life of Anthony (Athanasius the Great, 1857, pp. 837-976), which is, as is typical of biographies of 
Christian ascetics, reminiscent of such philosophical biographies as The Life of Apollonius of Tyana, The Life of Plotinus and The Life of Pythagoras. Frequently, ascetic literature expanded the notions of "specific topics of ancient philosophy - spiritual exercise, philosophical psychology and fight against passions" (Milko, 2009, p. 178), but detailed analysis reveals that the authors of ascetic texts presented a new philosophical understanding of the world, history and the position of man in society. Their spiritual and physical effort therefore brings forth a new philosophy, one accentuating perpetual self-improvement and a struggle against passions. In this view, asceticism is "the highest philosophical understanding of life, in which greed and egocentrism hurt relations between people" (Matsoukas, 2010, p. 406). Perfection ( $\tau \varepsilon \lambda \varepsilon i ́ \omega \sigma ı)$ of man, which is described by the term holiness ( $\dot{\alpha} \gamma i$ ó $\rceil \varsigma$ ), is not perceived as moral growth, but as a successful change and therapy of one's psychosomatic being. This is expressed e.g. in

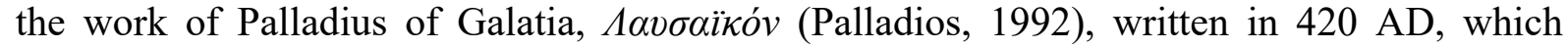
contains tales about prominent monks and is considered a jewel of ascetic philology.

\section{Connecting the definitions of philosophy by Constantine and John of Damascus}

Constantine understood philosophy in the second (knowledge of things Divine and human) and fourth (becoming like God) interpretation provided by John of Damascus, "with an addition of a Christian sense for acting in God's image and likeness", as M. A. Wesoły observes (Wesoły, 2020, p. 26). Thus, we may assume that Constantine's definition of philosophy hints at a direct connection to the definition by John of Damascus; the claim of "roots in Byzantine theology and theological thought" (Avenarius, 1992, p. 70) indicates that he was a theologian and,

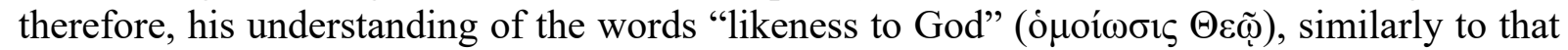
of John of Damascus, differs from Plato's.

In Byzantine ascetic literature, a great emphasis is placed on virtues ( $\dot{\alpha} \rho \varepsilon \tau \eta \dot{)}$ that lead man to perfection and unification with God. Man purifies oneself and becomes in God's likeness through ascetic preparation, reaching illumination that leads to perfection. Byzantine authors transformed these three stages - known from Neoplatonism as purification ( $\kappa \alpha \theta \alpha \rho \sigma ı)$ ), illumination ( $\varphi \omega \tau \imath \sigma \mu o ́ \varsigma)$ and perfection $(\tau \varepsilon \lambda \varepsilon i ́ \omega \sigma \iota \varsigma)$ - with regard to differences between the uncreated and created; and, on the basis of this, proposed the process of healing of the human mind through three stages of spiritual life: purification of heart, illumination of mind and

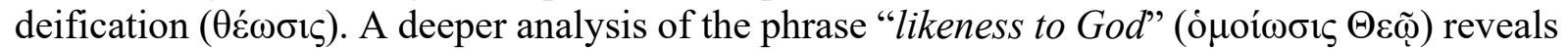
that, for Constantine, being in the likeness to God means deification $(\theta \dot{\varepsilon} \omega \sigma 1 \varsigma)$.

In this regard, it is necessary to reiterate that "Byzantine thought expands the ancient understanding of philosophy as ascent towards God. A fundamental and substantial difference of Byzantine thought is the description of meaning of this ascent as salvation, which represents deification" (Milko, 2009, p. 201). In Byzantine tradition, deification $(\theta \dot{\varepsilon} \omega \sigma 1 \varsigma)$ is the final goal of man, which is the reason why orthodoxy (oj $\rho o \delta o \xi i ́ \alpha)$ is closely linked to orthopraxy (o $\rho \theta 0 \pi \rho \alpha \xi i \alpha)$. It is exactly this aspect that Constantine emphasizes when he prays: "So that I would learn what pleases You (God) and was saved" (Život Konštantína-Cyrila, 2013, p. 15). Therefore, it is evident that Constantine strives "to be in the image and likeness of the One who created him by one's own actions" (Život Konštantína-Cyrila, 2013, p. 16) so that he would reach the final goal of Christianity, salvation.

In his philosophical works, Constantine the Philosopher probably leaned towards Christian interpretations and therefore founded his ideas primarily on Christian sources. It is possible that he built upon works of both Christian and non-Christian authors, after the example of his tutor Photios and his definition of philosophy was built on theological foundations. In this regard, it is important to remember that, in Byzantine thought, philosophy intertwined with theology and an exact definition of the substance of Byzantine philosophy depends largely on clearly determining the nature of philosophy and theology in the Byzantine Empire - one of the key issues yet to be tackled. Historians of philosophy have not been able to sufficiently delimit the 
contents of Byzantine philosophy, which leads to frequent misunderstandings in discussions of this topic. Furthermore, shortcomings of delimiting the contents of Byzantine philosophy and theology impede the proper understanding of the threshold of philosophy and theology, as well as their relations.

\section{Anthropological aspect of Constantine's definition of philosophy}

In addition to a gnosiological aspect, Constantine's definition of philosophy also incorporates an anthropological aspect, which is founded in the Byzantine notion of man's creation in God's image and likeness. The question of image has a long history and is among the core terms of Greek philosophy. It is used by Plato, the Stoics, as well as Neoplatonists later on. Philo of Alexandria also uses the term image and attributes to it an unusual meaning (Karavidopoulos, 1966, pp. 72-86).

Byzantine anthropology is founded on the Book of Genesis, describing the Divine origin of humanity: "So God created man in his own image, in the image of God he created him"3 (Gen 1, 27). This verse provides the first and most information on the presence of God's image in man and many Byzantine thinkers later continue along this line, among them Irenaeus of Lyons, Clement of Alexandria, Origen, Athanasius the Great, Gregory of Nyssa.

Despite the fact that the works of Byzantine authors do not contain a final statement or clear

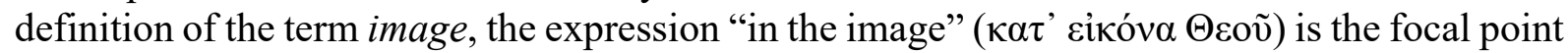
of their approaches to anthropological issues (Nellas, 1995, p. 20). In their texts, the question of image ${ }^{4}$ serves as a middle ground on which cosmology and anthropology meet each other. It is evident that the question of image, despite it being the cornerstone of Byzantine anthropology, cannot in itself exhaust all its facets.

John of Damascus ponders the question: "what is meant by 'according to his image and likeness""? (John of Damascus, 1860b, p. 168), answering it in much the same way as earlier Byzantine thinkers: "[it] means the intellect and free will" (John of Damascus, 1860b, p. 168). In the works of other Byzantine authors, God's image is attributed to the soul and body of man, in others to the division of nature and person, still in others to "the entirety of man" (Epiphanius of Cyprus, 1858, p. 344). That means that not only the soul, but also the body participates in God's image, as the first man was created according to his original (Kavasilas, 1865, p. 680). That original is the Logos that took on body. One does not comprise only the soul, nor only the body, but rather both the soul and body, which make up the being created in God's image. The expression "in the image" pertains to the entirety of man, that is, it relates to the entire human nature, i.e. both body and soul.

Byzantine thinkers sometimes even state that the Divine image in man only pertains to one part, such as soul, spirit, or freedom. However, even in these cases, they assume that man is not only the nature of such but, most importantly, a person that has a nature. Man is a unified personal whole, a unique being, to which John of Damascus testifies elsewhere:

"Thus, man is made up of soul and body, while neither the soul alone nor the body alone is called a hypostasis, but both are called enhypostata. That which consists of both is the hypostasis of both, for in the proper sense hypostasis is that which subsists of itself by its own subsistence, and such this is called" (John of Damascus, 1860a, p. 616). Similarly, Irenaeus of Lyons claims that the Divine image in man includes both soul and body, which was also made in God's image (Irenaeus, 1857, p. 1137). On the basis of the cited, it is evident that term image pertains to the entirety of man as a unique person that incorporates the entirety of nature, as it

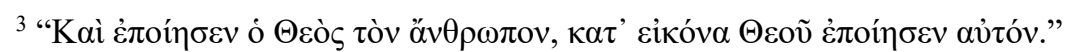

${ }^{4}$ The term "image" is meaningfully expanded in each new era in accordance with the issues faced by its thinkers; this influences the approach to clarifying various issues.

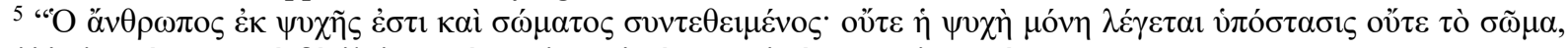

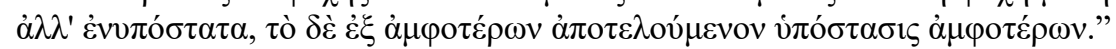


was man in his entirety that was called to life. It is this dynamic fulfilling of a human goal in which dwells the fullness of realization of human life in God's image and likeness.

What does Constantine the Philosopher mean by saying that man becomes "the image and likeness of the One who created him by his very actions" (Život Konštantína-Cyrila, 2013, p. 16)? The answer to this question now seems evident. He considers God to be his creator, who, to him, "appears to be the highest value" (Vaňko, 2013, p. 405). By performing one's deeds, man fulfils the potential possibility to achieve the Divine form, likeness of God ( $\alpha \alpha \theta^{\prime}$

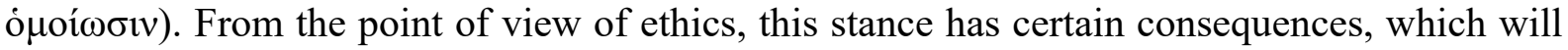
be discussed in the following section of the paper.

\section{Axiological aspect of Constantine's definition of philosophy}

Research of the axiological aspect of Constantine's definition of philosophy, on the basis of the contents of The Life of Constantine-Cyril, is impossible without comparisons with the Byzantine cultural environment and value standards of the period to which the CyrilloMethodian mission belongs. Considering the fact that the most prominent feature of this text content- and theme-wise is the description of individual stages of Constantine's life and deeds, axiological aspects represent only one among a multitude of components of the text's contentthematic structure (Vaňko, 2013, p. 404).

This description of ethical values is not intended to represent a philological analysis of The Life of Constantine-Cyril, but to point out the new code of ethics, through which the Slavs were offered new values leading to a change in the way of thinking and life. These new values were of Christian origin and introduced to the Slavic environment an ascetic way of life (Zozul'aková, 2016, pp. 149-157) and Byzantine understanding of virtues, as well as the Hesychast tradition that was transferred to Bulgarian, Serbian and Russian environments following the expulsion of Methodius' students from Great Moravia.

In this regard, it is vital to emphasize the fact that the Cyrillo-Methodian mission took place shortly after the resolution of the iconoclast controversy (Avenarius, 1998, pp. 85-90), which created space for the development of education, as indicated in the Introduction. In that period, there was a significant development of monastery life at the Holy Mount Athos near Thessaloniki, to where people travelled in search of the ideal ascetic way of life. The tradition of monasticism at Athos ${ }^{6}$ continued in the same nature as at Olympus, where Methodius lived as a monk after substituting earthly values for the heavenly and renouncing the world. Constantine, too, strove to please God, i.e. to observe God's commandments, and thus refused high rank and a life of luxury and "cared only for how to forsake the earthly matters for the heavenly" (Život Konštantína-Cyrila, 2013, p. 16). Thus, towards the end of his life, he became a monk in Rome and took on the name Cyril. This confirms that both brothers viewed the cultivation of human nature through the prism of ascetic struggle, that is, struggle against passions (non-ideal characteristics) and attainment of virtues. Therein lies the essence of Constantine's definition of philosophy, which can be extended also to the definition of ethical standards for behaviour in a Christian spirit - that is, the goal of human endeavours here is "to become in the image and likeness of the One who created him by own actions" (Život Konštantína-Cyrila, 2013, p. 16).

Within the Life of Constantine-Cyril, it is possible to identify several values that were essential for its author. These include knowledge of truth, repentance and life, self-restraint, prudence; wisdom; diligence; scholarship; as well as calmness in action (Život Konštantína-

\footnotetext{
${ }^{6}$ Monasticism first appeared in the area of Athos in the ninth century, thanks to the first organizer, Ioannis Kolovos; in the tenth century, Athanasius the Athonite - who previously lived as a monk at Olympus in Bithynia - founded the first great and well-organized monastery Great Lavra. Slavic societies were influenced especially by the Slavic monasteries at Athos: Zograf Monastery (Bulgarian) founded in 973, St. Panteleimon Monastery (Russian) founded in tenth century, and Hilandar Monastery (Serbian) founded in 1198.
} 
Cyrila, 2013, pp. 13-15). Education and knowledge (Život Konštantína-Cyrila, 2013, p. 16) were perhaps of the greatest value for Constantine, because he considered education to be the path to wisdom. This means that Constantine's definition of philosophy must be viewed within a wider context, and both his remarkable education and preference for Christian values need to be taken into account. In such manner, the anthropological and axiological aspects of Constantine's definition of philosophy seem to form a foundation for exploration of human behaviour in compliance with the Christian laws which encourage changes in ethical principles.

Via envoys, the Great Moravian prince, Rastislav, asked the Byzantine Emperor Michael III to send a teacher who would explain the essence of Christianity to Slavs in their language. The Emperor responded to Rastislav's request, writing in a letter: "Thus, accept a gift that is far more precious than all the gold, silver, gems and fleeting wealth" (Život Konštantína-Cyrila, 2013 , p. 33). With these very words, he appraised the diachronic value of Slavic script that was to develop in the following period. The Emperor further states: "God who wishes all people to be saved and to see the truth..." (Život Konštantína-Cyrila, 2013, p. 32). The meaning of the Old Church Slavonic word for truth also indicates justice, legal order, law, good law, which emerges from the Byzantine Empire "in every direction" (Život Konštantína-Cyrila, 2013, p. 32).

What does this, ultimately, mean? It means that a legal, ethical and hierarchical model of society was being brought to Great Moravia from the Byzantine Empire, through which the Slavs were provided with a new code of ethics, values and life. In this regard, Juraj Vaňko aptly states that the work of Constantine the Philosopher and Methodius in itself appears to be "a great, if not the greatest, value for the spiritual formation" of the Slavic nations (Vaňko, 2013, p. 405).

\section{Conclusion}

Constantine (Cyril) the Philosopher and his brother Methodius brought to the territory of Great Moravia not only the Slavic script and translations of various texts, but also many cultural elements, which then formed the value system of Slavs in Central Europe (Gluchman, 2017, pp. 62-74; Gluchman, 2019, pp. 106-118). These elements were transferred to everyday life, significantly influenced the direction of other Slavic nations and their position in the European cultural space (Ivanič, 2016, pp. 123-130; Hetényi, 2016, pp. 233-243). By defining philosophy along the lines of the definition proposed by John of Damascus, Constantine delimited the aim of human life and directed man to become - through one's own deeds - an image and likeness of God that made him. This topic is closely linked to the issue of the value platform of Byzantine philosophy, which reflects Byzantine heritage (Pružinec, 2019, p. 136) and expands the deeper understanding of the meaning of human life. The issue of values currently appears to be very topical, since it is related to a wide range of axiological questions and its research involves utilization of a number of scientific disciplines - philosophy, ethics, psychology, sociology, and linguistics (Vaňko, 2013, p. 404).

\section{Acknowledgement}

This work was supported by the Slovak Research and Development Agency under contract No. APVV-16-0116

\section{References}

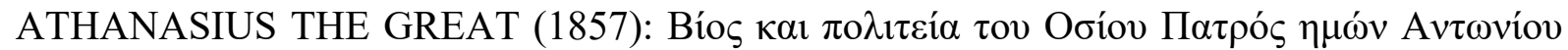
[Life of Antony]. In: Patrologiae cursus completus, edited by J. P. Migne. Paris, vol. 26, pp. 837-976.

AVENARIUS, A. (1992): Byzantská kultúra v slovanskom prostredí v VI.-XII. storoči [Byzantine culture in the Slavic environment in 6-12th centuries]. Bratislava: Veda. 
AVENARIUS, A. (1998): Byzantský ikonoklazmus 726-843: storočie zápasu o ikonu [Byzantine Iconoclasm 726-843: history of the icon]. Bratislava: Veda.

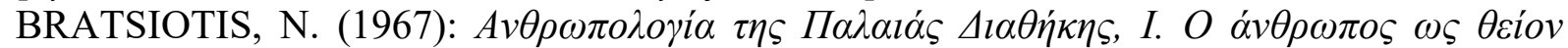

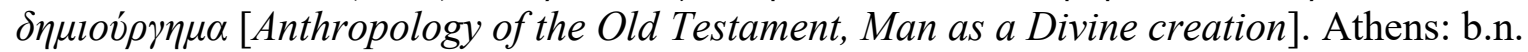

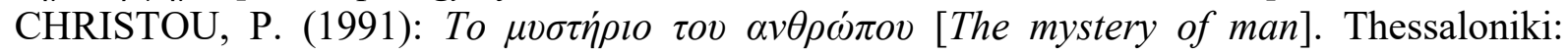
Kvpouávos.

DOSTÁLOVÁ, R. (2004): Pozemský svět jako škola lidských duší. In: K. Korteová (ed.): Basil $z$ Caesareje. Devět kázaní o stvořeni světa [Basil of Caesarea: Nine sermons on creation of world]. Prague: Oikoumene, pp. 7-26.

DUPKALA, R. (2006): Reflexie európskej filozofie na Slovensku [Reflections of European philosophy in Slovakia], 2nd ed. Prešov: Impresso.

DVORNÍK, F. (1970): Byzantské misie u Slovanů [Byzantine missions among Slavs]. Prague: Vyšehrad.

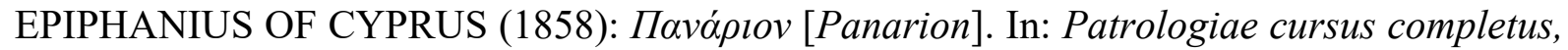
edited by J. P. Migne. Paris, vol. 42, English trans. R. McCambly, pp. 173-1200.

GLUCHMAN, V. (2017): Krest'anstvo a morálka v stredoeurópskej politike 9. storočia. [Christianity and morality in central European politics of the 9th Century]. In: Konštantínove listy, 10(2), pp. 62-74.

GLUCHMAN, V. (2019): The literary works as a code of ethics in Great Moravia. In: Ethics \& Bioethics (in Central Europe), 9(3-4), pp. 106-118.

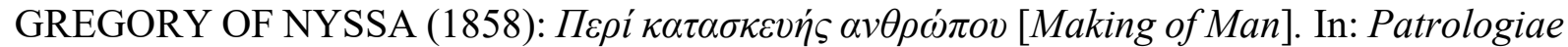
cursus completus, edited by J. P. Migne. Paris, vol. 44, English trans. H. A. Wilson, pp. 123256.

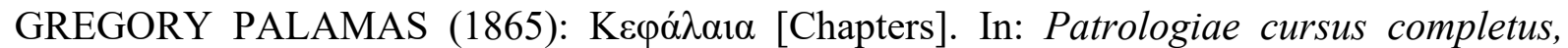
edited by J. P. Migne. Paris, vol. 150, pp. 1121-1226.

HETÉNYI, M. (2016): Mission of Saints Cyril and Methodius and their contacts with Kocel, duke of Pannonia. In: European Journal of Science and Theology, 12(6), 233-243.

HETÉNYI, M. (2019): Cyrilo-metodský kult a religiozita na Slovensku v 19. - 21. storočí [The cyrillo-methodian cult and religiosity in Slovakia from the 19th to the 21st century]. In: Konštantínove listy, 12(1), pp. 141-158.

IERODIAKONOU, K. \& ZOGRAFIDIS, G. (2010): Early Byzantine philosophy. In: L. P. Gerson (ed.): The Cambridge history of philosophy in late antiquity, vol. II. Cambridge: Cambridge University Press, pp. 843-868.

IRENAEUS (1857): Adversus haereses [Against heresies]. In: Patrologiae cursus completus, edited by J. P. Migne. Paris, vol. 7, English trans. A. Roberts, pp. 433-1224.

IVANIC, P. (2016): The origins of Christianity in the territory of Czech and Slovak republics within the contexts of written sources. In: European Journal of Science and Theology, 12(6), pp. 123-130.

IVANIČ, P. (2020): Christianization of the territory of today's Moravia and Slovakia before 863. In: Bogoslovni Vestnik, 80(3), pp. 655-667.

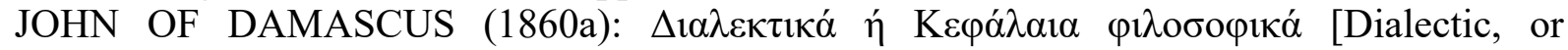
Philosophical Chapters]. In: Patrologiae cursus completus, edited by J. P. Migne. Paris, vol. 94, English trans. F. H. Chase, Jr., pp. 521-780.

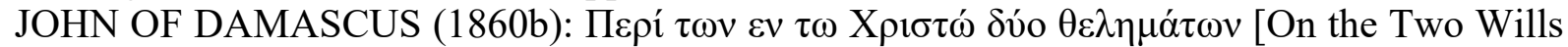
in Christ]. In: Patrologiae cursus completus, edited by J. P. Migne. Paris, vol. 95, English trans. F. H. Chase, Jr., pp. 127-186.

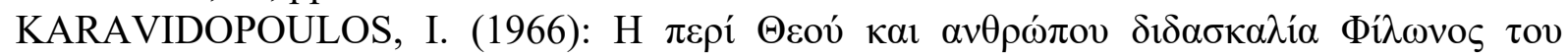

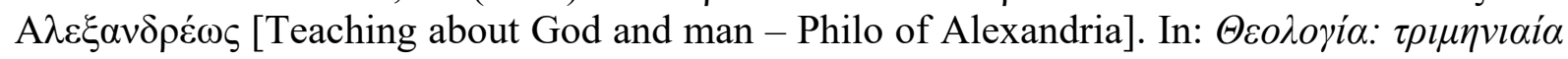

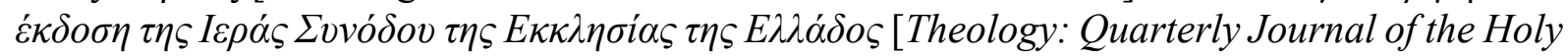
Synod of the Church of Greece], 37(1), pp. 72-86. 


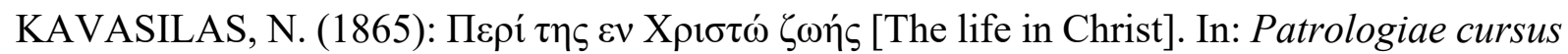
completus, edited by J. P. Migne. Paris, vol. 150, English trans. C. J. deCatanzaro, pp. 493725.

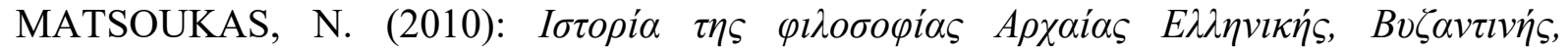

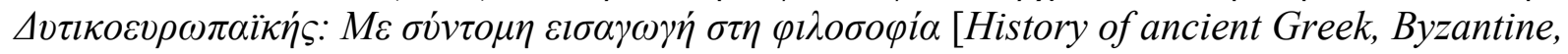
Western European philosophy: With a brief introduction to philosophy]. Thessaloniki: П. Поopvapás.

MILKO, P. (2009): Úvod do byzantské filosofie [Introduction to Byzantine philosophy]. Červený Kostelec: Pavel Mervart.

MILKO, P. (2016): Vybrané otázky byzantské filosofie [Selected questions of Byzantine philosophy]. In: Konštantínove listy, 9(1), pp. 119-135.

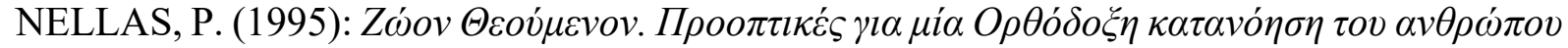

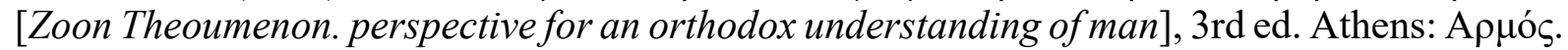

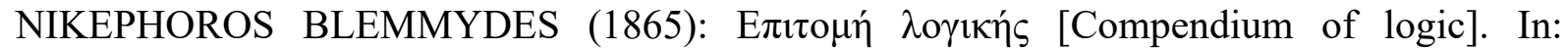
Patrologiae cursus completus, edited by J. P. Migne. Paris, vol. 142, pp. 686-1004.

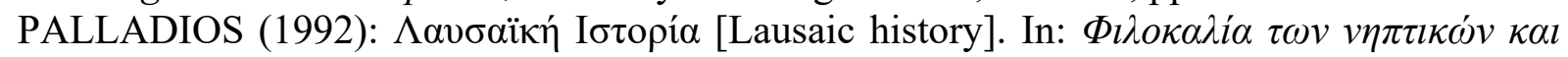

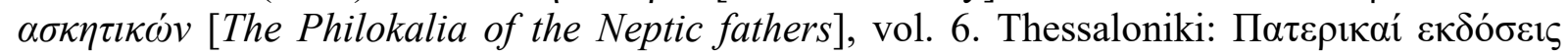

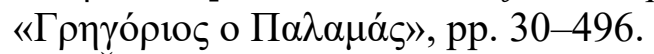

PRUŽINEC, T. (2019): Sondy do hodnotovej platformy byzantskej filozofie a jej odkaz pre súčasnú európsku hodnotovú orientáciu: náčrt problematiky [Probes into the value platform of Byzantine philosophy and its message to contemporary European value orientation: A sketch of the issue]. In: Konštantínove listy, 12(2), pp. 135-147.

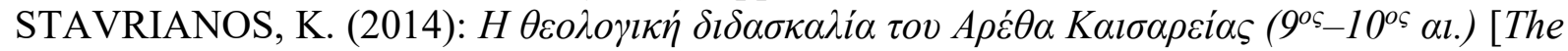

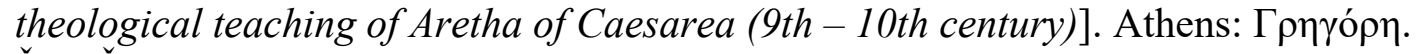

ŠEVČENKO, I. (1956): The definition of philosophy in the life of Saint Constantine. In: M. Halle, H. G. Lunt, H. McLean \& C. H. Van Schoone-Veld (eds.): For Roman Jakobson: Essays on the occasion of his sixtieth birthday. The Hague: Mouton, pp. 449-457.

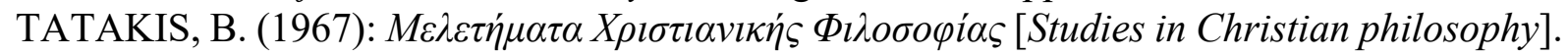

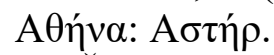

VAŇKO, J. (2013): Axiologické aspekty v Životoch slovanských apoštolov Cyrila a Metoda [Axiological aspects in the lives of the Slavic Apostles Cyril and Methodius]. In: T. Baník \& M. Lukáčová (eds.): Tradícia a prítomnost' misijného diela sv. Cyrila a Metoda [The tradition and presence of the missionary work of St. Cyril and Methodius]. Nitra: Univerzita Konštantína Filozofa v Nitre, pp. 404-409.

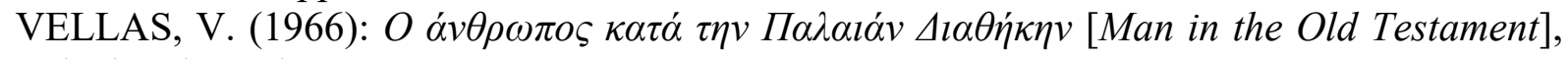
3rd ed. Athens: b.n.

WESOŁY, A. M. (2020): Constantine the Philosopher, who was he? In: Konštantínove listy, 13(2), pp. 22-34.

ZOZULAKOVÁ, V. (2016): Praktická filozofia v živote Konštantína a Metoda [Practical philosophy in the lives of Constantine and Methodius]. In: Konštantínove listy, 9(1), pp. 149157.

ŽIVOT KONŠTANTÍNA-CYRILA (2013). [Life of Constantine-Cyril]. In: A. Škoviera (ed.): Pramene o živote svätých Cyrila a Metoda a ich učenikov [Sources about the life of Saints Cyril and Methodius and their disciples]. Bratislava: Post Scriptum, pp. 9-40. 